\title{
PENGGUNAAN MEDIA GAMBAR KARTUN TERHADAP RASA NASIONALISME MATA PELAJARAN PKN DI KELAS X SMK ALAWIYAH PASPAN, KECAMATAN GLAGAH, KABUPATEN BANYUWANGI TAHUN PELAJARAN 2017/2018
}

\author{
Umi Yasiroh ${ }^{1}$, Roudhotul Jannah ${ }^{2}$ \\ SMK ALAWIYAH PASPAN GLAGAH \\ email: shifapermatasari@yahoo.co.id roudhotulj15@gmail.com
}

\begin{abstract}
ABSTRAK
Penelitian ini bertujuan mengetahui pengaruh penggunaan media gambar kartun terhadap rasa nasionalisme mata pelajaran PKN pada siswa kelas X SMK Alawiyah. Penelitian ini merupakan menggunakan metode penelitian kuantitatif dengan penggunaan quasi eksperimen atau eksperimen semu yaitu metode penelitian yang menguji hipotesis berbentuk hubungan sebab-akibat melalui dan yang perlakuan dan menguji perubahan yang diakibatkan oleh perlakuan tersebut (Suharsimi Arikunto:2009). Subjek penelitian ini adalah siswa kelas X. Populasi penelitian berjumlah 60 orang siswa dan random sampling 36 orang siswa.Teknik pengumpulan data menggunakan observasi menyatakan lima aspek penilaian siswa skornya 3,23 yang berati hasilnya baik, dan hasil observasi guru menyatakan lima aspek penilaian guru skornya 3,00 yang berati hasilnya baik dan kuesioner menyatakan rata-rata skor yaitu 75 yang berati positif dengan pengujian hipotesis menggunakan anava satu jalur menyatakan Fhitung lebih besar dari Ftabel 3,35 yakni hasilnya 0,05 4,78. Hal ini menunjukkan bahwa terdapat pengaruh media gambar kartun terhadap rasa nasionalisme untuk membangun dan bertanggung jawab akan kesadaran pentingnya wawasan nusantara dalam konteks NKRI pada mata pelajaran PKN di kelas X TKJ SMK Alawiyah. Penggunaan media gambar kartun menambah antusias semangat siswa dalam belajar, serta nasionalisme siswa yang paling menonjol yaitu berdemokrasi yang langsung, umum, bebas rahasia, jujur dan adil seperti dalam gambar kartun.
\end{abstract}

Kata kunci :quasteksperimen; gambar kartun; nasionalisme;demokrasi; mata pelajaran PKN.

\section{PENDAHULUAN}

Pendidikan adalah usaha sadar dan terencana untuk mewujudkan suasana belajar dan proses pembelajaran agar peserta didik secara aktif mengembangkan potensi dirinya untuk memiliki kekuatan spiritual keagamaan, pengembangan diri, kepribadian, kecerdasan, akhlak mulia, serta keterampilan yang diperlukan dirinya, masyarakat, bangsa dan negara (Arifin, dalam Ahmad Zainudin Arifin 2013)

Undang-undang RI No. 20 tahun 2003 tentang sistem pendidikan nasional dijelaskan bahwa pendidikan nasional berfungsi mengembangkan kemampuan dan membentuk watak serta peradaban bangsa yang bermartabat dalam rangka mencerdaskan kehidupan bangsa, bertujuan untuk berkembangnya potensi peserta didik agar menjadi manusia yang beriman dan bertakwa kepada Tuhan Yang Maha Esa, berahlak mulia, sehat, berilmu, cakap, kreatif, mandiri dan menjadi warga negara yang demokratis, bertanggung jawab serta nasionalisme yang tinggi.Dalampenelitianterdahulumenurut Tri Mulyati dan Dhalia Soetopo (2017) bahwa kartun merupakan salah satu media belajar yang menghibur, gambar-bambar kartun dalam pembelajaran diharapkan siswa menyukai materi pelajaran dan memahami materi, sehingga siswa dapat menerima pelajaran yang dipelajarinya.Menurut Sudjana dan Rifai, dalam Anjayudin (2014) 
bahwa "sesuai wataknya kartun yang efektif akan menarik perhatian serta menumbuhkan minat belajar siswa". hal ini menunjukan bahan-bahan kartun bisa menjadi alat memotivasi yang berguna dikelas.

SMK Alawiyah Paspan, kecamatan Glagah, kabupaten Banyuwangi merupakan sebuah lembaga pendidikan formal menengah kejuruan yang umumnya selalu diajar dengan model pembelajaran langsung khususnya metode ceramah menunjukkan bahwa siswa kurang bersemangat dalam menerima pelajaran dan menimbulkan kejenuhan siswa. Ketika belajar didalam kelas, siswa mengetahui yang dijelaskan oleh guru namun apabila keluar dari proses belajar mengajar, kurang sekali pengetahuan yang diberikan oleh guru membekas dibenak mereka. Disamping hal tersebut, gangguan dalam kelas ketika pembelajaran berlangsung besar, perhatian siswa juga rendah karena dalam proses belajar mengajar siswa terkadang mengantuk.

Berdasarkan kenyataan tersebut diatas, maka perlu dilakukan perbaikan dalam kegiatan pembelajaran agar nilai siswa meningkat. Masalah-masalah dalam proses pembelajaran seperti kejenuhan dan kurangnya semangat siswa, gangguan dalam kelas, serta perhatian siswa yang rendah karena mengantuk perlu segera diatasi. Salah satu solusi pemecahannya adalah dengan penggunaan media pembelajaran. Media yang digunakan dapat menarik siswa untuk semangat belajar. Media banyak macamnya, salah satunya adalah media gambar kartun, yang merupakan salah satu contoh pemanfaatan teknologi dalam menunjang proses pendidikan. Media ini dapat meningkatkan semangat dan perhatian siswa untuk belajar, sehingga gangguan dalam kelas dapat diminimalisir, demikian juga bagi siswa yang mengantuk, akan membuat mereka tergerak untuk memperhatikan pelajaran. Dalam hal ini pembelajaran PKN adalah sebagai salah satu pelajaran yang penyampaiannya lebih mudah dengan menggunakan media, dengan demikian dalam penelitian ini penulis menggunakan media gambar kartun yang disajikan berisi tentang rasa nasionalisme dalam materi wawasan nusantara dengan ilustrasi-ilustrasi gambarkartun.

Berangkat dari pemikiran, penelitian yang serumpun dan latar belakang diatas dipandang perlu dilakuan penelitian yang lebih luas dan dalam yang bersifat eksplenatif. Peneletian skripsi ini bermaksud untuk mengetahui pengaruh penggunaan media gambar kartun terhadap rasa nasionalisme dalam membangun wawasan nusantara dalam konteks NKRI sebagai anugerah Tuhan YME dan rasa bertanggung jawab mengembangkan kesadaran akan pentingnya wawasan nusantara dalam konteks NKRI kelas $\mathrm{X}$ TKJ di SMK Alawiyah Paspan, kecamatan Glagah, kabupaten Banyuwangi pada tahun pelajaran $2017 / 2018$

\section{METODE PENELITIAN}

Metode yang digunakan dalam penelitian ini adalah metode penelitian kuantitatif dengan penggunaan quasi eksperimen atau eksperimen semu yaitu metode penelitian yang menguji hipotesis berbentuk hubungan sebab-akibat melalui dan yang perlakuan dan menguji perubahan yang diakibatkan oleh perlakuan tersebut (Suharsimi Arikunto:2009). Karena berbagai hal yang berkenaan dengan pengontrolan variabel, sehingga sulit digunakan eksperimen murni.

Metode penelitian ini menggunakan kelompok eksperimen. Yaitu metode penelitian yang melakukan pengontrolan terhadap salah satu variabel. Kelompok eksperimen diberi perlakuan khusus (variabel yang akan diuji akibatnya) yaitu dengan menggunakan media gambar kartun. Penelitian ini menggunakan kuesioner sebagai alat pengumpulan data dan diperkuat dengan observasi pada guru dan siswa. Peneliti menggunakan responden kelas $\mathrm{X}$ SMK Alawiyah. Populasi siswa kelas X SMK Alawiyah adalah sebanyak 60 siswa yang terdiri dari jurusan TKJ, TSM, dan TB. Peneliti memutuskan mengambil sampel sebanyak 
36 orang siswa diambil dari kelas TKJ. Jumlah tersebut sudah dirasa cukup dan representatif terhadap populasi keseluruhan.

Hasil observasi digunakan untuk memperoleh data pengelolaan penggunaan media gambar kartunyang dianalisis dengan menghitung rata-rata setiap aspek pada setiap pertemuandenganmenggunakanrumus:

Rata-rata skor pengelolaan kelas

$$
=\frac{\text { jumlah Nilai Keseluruhan }}{\text { Banyaknya Aspek yang Diamati }}
$$

Hasil kuesioner digunakan untuk menghitung jumlah nilai siswa untuk setiap butir pernyataan dengan rumus berikut.

$\mathrm{NRS}=\sum$ NRS ke-i

\section{$=$ NRSSS+NRS S+NRS KS+NRS TS}

Keterangan:

NRS $=\sum$ NRS ke-i $=$ jumlah angket respond siswa pada butir pernyataan ke-i

$$
\mathrm{i}=\text { nomor pernyataan (1-30) }
$$

Menghitung presentase angket siswa dari setiap butir pernyataan dengan menggunakan rumus sebagai berikut:

\begin{tabular}{l}
$\%$ NRS $=$ \\
$\frac{\text { NRS }}{\text { NRS Maksimum }} \times 100 \%$ \\
\hline
\end{tabular}

(Manoy, 2016)

Menentukan kriteria persentase angket siswa untuk setiap butir pernyataan.

$$
\begin{aligned}
& 0 \% \leq \mathrm{NRS}<20 \% \text { : sangat lemah } \\
& 20 \% \leq \mathrm{NRS}<40 \% \text { : lemah } \\
& 40 \% \leq \mathrm{NRS}<60 \% \text { : cukup } \\
& 60 \% \leq \mathrm{NRS}<80 \% \text { : kuat } \\
& 80 \% \leq \mathrm{NRS} \leq 100 \% \text { : sangat kuat }
\end{aligned}
$$

\section{HASIL DAN PEMBAHASAN}

Berdasarkan hasilpenelitian diketahui dari 30 item yaitu 7 item SANGAT KUAT yaitu item nomor 1,2, 4. 5, 6, 14 dan 27. Kemudian terdapat 21 item yang menyatakan KUAT yaitu nomor 7, 8, 9, 10, $11,12,13,15,16,17,18,19,20,22,23,24$, 25, 26, 28, 29 dan 30. Dan terdapat 2 item yang menyatakan CUKUP yaitu nomor 3 dan 21. Karena hasil rata-rata dari 30 instrumen itu adalah $77 \geq 50 \%$, maka respon siswa dikatakan positif.

Dari hasil observasi siswa dapat dilihat jumlah total aspek yang pertama 137 dengan rata-rata 3,81 . Jumlah aspek yang kedua adalah 136 dengan rata-rata 3,78. jumlah aspek ketiga adalah 137 dengan rata-rata 3,8. Jumlah aspek keempat adalah 105 dengan rata-rata 2,92. Dan jumlah aspek kelima adalah 66 dengan rata-rata 1,83. Kemudian dijumlahkan nilai keseluruhan hasilnya adalah 16,14 kemudian dibagi jumlah aspek kelima dan terdapat hasil rata-rata 3,23 masuk dalam kategori baik. Kesimpulannya adalah respon siswa dalam penggunaan media gambar kartun menunjukkan ketertarikan dan dapat memberi semangat siswa dalam menerima materi dengan baik.

Sedangkan dari hasil observasi guru yang meliputi 15 item masing skor yang diperoleh peritem yaitu 3. Dapat dijumlahkan total dari kelima aspek tersebut dengan nilai 45 kemudian dibagi dengan jumlah aspek yaitu dibagi 5 dan mendapatkan rata-rata 3,00. Pada kriteria pengelolaan pembelajaran masuk dalam kategori baik. Kegiatan pembelajaran merupakan salah satu kewajiban dasar dari seorang guru kepada siswanya yang harus diperhatikan dengan benar dan cermat. Salah satu tujuan dari kegiatan pembelajaran khususnya adalah untuk memberikan pemahaman terhadap materi yang diberikan oleh guru kepada siswa. Media pembelajaran yang tepat akan memberikan dampak yang positif terhadap pemahaman materi yang diberikan sehingga siswa mampu menguasai materi yang diberikan dengan baik. Hasil akhir yang diharapkan adalah peningkatan rasa nasionalisme dalam materi wawasan nusantara siswa yang dilihat dari aspek kognitif dan psikomotorik.

Berdasarkan penjabaran deskripsi data sebelumnya, dapat dilihat bahwa respon siswa kelas $\mathrm{X}$ TKJ dalam pembelajaran dengan media gambar kartun sangat baik. Terbukti bahwa dalam pengujian hipotesis yang menyatakan Fhitung lebih besar dari 
Ftabel yaitu $0,05 \geq 4,78$ yang berarti ada pengaruh penggunaan media gambar kartun yang positif dan signifikan terhadap rasa nasionalisme membangun dan bertanggung jawab akan kesadaran pentingnya wawasan nusantara dalam konteks NKRI.Nana Sudjana dan Ahmad Rifai dalam Gita Enggarwati (2014) menyebutkan bahwa pemanfaatan media pembelajaran dalam proses belajar mengajar siswa dapat menjadikan pengajaran lebih menarik perhatian siswa sehingga dapat menumbuhkan motivasi belajar siswa. Penggunaan media tersebut dapat menjadikan siswa lebih banyak melakukan kegiatan belajar, artinya dapat menjadikan siswa untuk selalu aktif di dalam proses pembelajaran.

Diketahui bahwa peningkatan rasa nasionalisme yang ditunjukkan beberapa siswa adalah mampu memahami materi wawasan nusantara dengan baik melalui media gambar kartun dan mereka dengan bangga berani mencalonkan diri sebagai calon ketua OSIS pemilu yang akan datang di dalam proses pembelajaran PKN.Perilaku siswa tersebut merupakan dampak dari penggunaan media gambar kartun oleh guru yang menggambarkan nilai-nilai kepemimpinan yang baik serta nilai-nilai berdemokrasi langsung, umum, bebas, rahasia, jujur dan adil yang merupakan cerminan rasa nasionalisme yang harus dimiliki oleh tiap individu. Hal tersebut sesuai dengan pendapat yang dikemukakan olehBahar Buasan (2012: 10) juga berpendapat bahwa jika nasionalisme dapat ditanamkan pada rakyat Indonesia, maka akan tercipta sumber daya manusia yang tidak sekedar berkualitas namun memiliki rasa bangga dan cinta terhadap bangsa dan tanah air Indonesia.

\section{SIMPULAN}

Berdasarkan hasil dan pembahasan penelitian dapat disimpulkan bahwa kuesioner dan observasi siswa yang menggunakan media gambar kartun lebih membuat siswa antusias belajar dan mudah memahami materi PKN. Dapat dilihat dari pengujian hipotesis dengan Anava satu jalur menyatakan Fhitung lebih besar dari Ftabel yakni $0,05 \geq 4,78$. Dan hasil kuesioner yang menyatakan rata-rata skor yaitu 75 yang berati positif. Dari hasil observasi siswa menyatakan lima aspek penilaian siswa skornya 3,23 yang berati hasilnya baik, dan hasil observasi guru menyatakan lima aspek penilaian guru skornya 3,00 yang berati hasilnya baik. Hal ini menunjukkan bahwa terdapat pengaruh media gambar kartun terhadap dalam meningkatkan rasa nasionalisme untuk membangun dan bertanggung jawab akan kesadaran pentingnya wawasan nusantara dalam konteks NKRI pada siswa kelas X SMK Alawiyah.

\section{DAFTAR PUSTAKA}

Ahmad Zainul Arifin (2013) Pemanfaatan Media Animasi Dalam Peningkatan Hasil Belajar Pada Pembelajaran Shalat kelas $V$ di SDN 2 Semangkak Klaten Tengah Jawa Tengah. Skripsi: Jurusan Pendidikan Agama Islam Fakultas Ilmu Tarbiyah dan Keguruan UIN Sunan Kalijaga Yogyakarta

Anjayudin (2013) "Pengaruh Penggunaan Media Gambar Kartun terhadap Hasil Belajar Ips pada Siswa Kelas VIII SMP Al-Amanah Setu, Tangerang Selatan Tahun 2013/2014" diakses 9 maret 2018.Pukul 11.37 WIB.

Arief S. Sudiman, dkk (2008) Media Pendidikan: Pengertian,

Pengembangan, dan

Pemanfaatan, Jakarta:PT. Raja Grafindo

Buchari Alma (2009) Pengantar Statistika (Bandung: Alfabeta)

Gita Enggarwati (2014) UNY Penanaman Sikap Nasionalisme mata pelajaran IPS Siswa kelas IV SDN 2 Sumampi diakses pada tanggal 27 Mei 2018 pukul 01.00 http://eprints.uny.ac.id/13730/1/Skrips 
i_Gita\%20Enggarwati_09108244016. pdfS

Jenis-Jenis

kartun

https://tentangkartunku.wordpress.co m/2013/01/06/jenis-jenis-kartun/ diakses pada 25 April 2018 pukul 22.50

Kartun dan Seni Ilustri .Artikel diakses pada 25 April 2018 pukul 22.15

Manoy, I. S. (2016). Efektivitas Pembelajaran Matematika dengan Menggunakan Soal Open-Ended Pada Metode Penugasan Disertai Pemberian Umpan Balik. Jurnal Ilmiah Pendidikan Matematika,Volume 6 No 1, 183-190.

Suharsimi Arikunto, DasardasarEvaluasiPendidikan, (Jakarta: BumiAksara, 2009)

Tri Mulyati dan Dhalia Soetopo (2017) Pengembangan media komik digital berbasis budaya lokal Banyuwangi pada mata pelajaran bahasa inggris untuk kelas VIII SMPN Kalipuro, Banyuwangi

Undang-Undang RI No. Tahun 2003 Tentang Sistem Pendidikan Nasional Tahun 2003, Jakarta:CV. Mini Jaya Abadi

Wahyudi.(2015).TujuanInstruksional http://blog.unnes.ac.id/seputarpendidikan/2 015/10/19/tujuan-instruksionalumum-dan-tujuan-instruksionalkhusus-pendidikan/diakses tanggal 1 Mei 2018 pukul 00.10 